\title{
Intuitionism in Contemporary Polish Ethics. Part I. From Modernism to the Lviv-Warsaw School
}

DOI: http://dx.doi.org/10.12775/RF.2019.062

The importance and role of intuition in ethics, as in the philosophy of cognition and science, is far from being unambiguous. This is the result of a long history of reflection on the initial sources of knowledge and the criteria of its adequacy and certainty. The common language, which sometimes permeates philosophy, especially practical philosophy, associates intuition with feeling, hunch, instinct. In the sciences there is a conviction that without intuition there can be no cognition, discoveries, creativity, and that there is no reasoning without premises provided by direct cognition. The book Knowledge and intuition (2008) describes various fields of cognition in which intuition occurs - in mathematics, psychology, mysticism, philosophy, and ethics. ${ }^{1}$ It is often noticed that there are as many varieties of intuition as there are areas of cognition. In the history of philosophy, intuition was understood as the knowledge of the Absolute, as a priori cognition without empirical basis, but also as a direct, experiential, obvious cognition of the individual and concrete. The ambiguity of the concept of intuition in philosophy was limited by Henry Bergson's intuitionism, for whom it was the instinct of direct

${ }^{1}$ Cf. Wiedza a intuicja, ed. Alina Motycka (Warszawa: Wydawnictwo IFiS PAN, 2008). Cf. Anna Drabarek, "Intuicyjne poznawanie dobra w rozważaniach G. E. Moore'a i W. Tatarkiewicza", ibidem. 
cognition of concrete, living, changing reality. Intuition was contrasted with the intellect that simplifies the image of the world.

Alongside Bergson's intuitionism, a methodological current of ethical thought developed in the twentieth century, which saw the proper cognitive basis of ethics in direct, a priori, in fact intuitive, cognition. Previously, moral philosophy was supposed to refer to the direct cognitive starting point of ethics, especially in the Enlightenment's theory of the moral sense and in opposition to Immanuel Kant's apriorism. The discussion about the cognitive foundation of ethics was enlivened by George E. Moore, who in his book Principia Ethica (1903) accused the previous ethics of a "naturalistic error". ${ }^{2}$ The nature and subject of intuition were discussed with Moore by Harold A. Prichard and Wiliam D. Ross, and others. On the continent, in turn, intuitive character was attributed to the ethical views of Franz Brentano, Edmund Husserl, Max Scheler, Nicolai Hartmann, and others. British intuitionism was intellectualistic, while on the continent it varied, but the emotionalistic approach prevailed, in which Scheler in particular considered the emotional a priori as the basis of ethics.

In Poland at the beginning of the twentieth century, the work of these philosophers was already known. The intuitionism in the ethics of G.E. Moore and - in Poland - the intuitionism of W. Tatarkiewicz were pointed out by Kazimierz Twardowski in his lectures. ${ }^{3}$ In the 1960s in Poland critical meta-ethical research on intuitionism and emotionism was conducted by Marek Fritzhand (1913-1992), especially in his book Main Issues and Directions of Meta-ethics. On Meta-ethics, Intuitionism and Emotivism (Warsaw 1970). The author distinguished between quasi-perceptive and quasi-mathematical intuitionism, the first of which is analogous to perceptive, empirical cognition (Moore), the second to cognition analogous to mathematical cognition (Prichard). The intuitive nature of the cognitive foundations of ethics in the views of some Polish philosophers was observed by Fritzhand's student Stanislaw Soldenhoff (1928-2019) in the introduction to his book On Ethical Intuitionism. Duty and value in the W. D. Ross system (Warsaw 1969). There, the author formulated an initial classification of the understanding of intuition in ethics and intuitionism, dividing it into rationalistic (intellectual), characteristic of British intuitionists of the twentieth century and some Polish ethicists, and intuitionism based on feelings of good, characteristic

${ }^{2}$ Cf. George E. Moore, Zasady etyki, transl. Cz. Znamierowski (Warszawa: Wydawnictwo M. Arcta, 1919).

${ }^{3}$ Cf. Kazimierz Twardowski, "O sceptycyzmie etycznym. Wykładów z etyki część II", compiled by Izydora Dąmbska, on the basis of outlines mainly from 1923/1924, Etyka 9 (1971). 
of phenomenologists, referring to B. Pascal and D. Hume, who rejected the competence of reason in the matter of knowing values. ${ }^{4}$

Twenty years later, Anna Drabarek devoted a monograph On learning about the moral good. A different understanding of intuition in Polish ethics (Lublin 1999) to the problem of intuition in Polish ethics. The list of philosophers discussed there, who placed the cognitive foundation of ethics in the sphere of intuition, does not fully coincide with those to whom this article has been devoted, and the conclusions from the analysis of differences and the evolution of the understanding of intuition in ethics take a different direction. The author of the monograph records the differences in the understanding of intuition, but there is no attempt at a deeper typology of intuition and intuitionism. In the article Intuitionism in the axiology of Wtadystaw Tatarkiewicz (Torun 1979), ${ }^{5}$ the author of this paper tried to make a preliminary classification of the types of intuitionism, but in retrospect it does not seem entirely clear. Hence the return to the issue of intuitionism in Polish ethics.

The problem of the place and role of intuitiveness in ethical cognition has become much more complicated in the recent history of ethics. More emphasis has been placed on the methodological analysis of tradition, and the destructive criticism of ethics as a science, brought against it by emotionism, which accuses ethics of senselessness and persuasiveness, must be rejected. The literature that has developed around a critical analysis of the "naturalistic error" has shown weaknesses in intuitionism, but has not provided a satisfactory answer to the question concerning the cognitive foundation of ethics. But in rejecting naturalism one would have to point out the cognitive power for ethics to be reliable or at least better justified. There is no good climate in Europe for continuing to study the legitimacy of intuition in ethics. In America, the philosopher of the younger generation Michael Huemer recently defended intuitionism in his book Ethical Intuitionism (2005). In defence of ethical intuitionism, the author uses arguments that have also been discussed in the Polish ethics of the twentieth century, so it is worth coming back to this ethics to better understand the meaning and role of intuition in ethics.

${ }^{4}$ Cf. Stanisław Soldenhoff, $O$ intuicjonizmie etycznym. Obowiazek $i$ wartość w systemie W. D. Rossa (Warszawa: PWN, 1969), 14-18. W. Tatarkiewicz and T. Czeżowski have been included in the rationalist kind of ethical intuitionism in Poland.

${ }^{5}$ Cf. Ryszard Wiśniewski, "Intuicjonizm w aksjologii Władysława Tatarkiewicza", Acta Universitatis Nicolai Copernici, Filozofia 4, 103 (Toruń 1979): 123-124, where the following typology of intuitionism was built: 1) empirical-logical, 2) empirical-emotionalist, 3) rationalistic apriorism, 4) mystical, irrationalistic. 


\section{At the Sources of Intuitionism and Anti-Naturalism in Polish Ethics}

The turn of the nineteenth and twentieth centuries is marked by two positions. The first is the Post-Romantic intuitionism in experimental metaphysics of Edward Abramowski (1868-1918). He was a philosopher, psychologist, and sociologist, a socialist who promoted the ideal of brotherhood and solidarity. In his psychological research he drew attention to two sides of the cognitive process, active and passive. The former is subjective, the latter objective, and it is the latter that leads, in his opinion, to the subconscious, allows one to reject the moment of apperception, the activity of the intellect, to stop attention, to submit to intuition, directness, feelings. Abramowski calls these intuitions agnosia. ${ }^{6}$ The content of ethical agnosia is resistance to harm, to the suffering of living beings, a sense of unity with everything that exists, and here - a sense of brotherhood. In the Experimental Metaphysics, published decades later on the basis of manuscripts and notes, the ethical agnosia was characterized as one of the thirteen, close to religious and love agnosia, as "a special touch of heart at the sight of human misery and harm; real and individual harm." ${ }^{7}$ When analysing conscience, Abramowski wrote: "We are troubled by the incompatibility of our conduct with the known pattern, i.e. the ideal, even when this pattern is not yet realized or when we cannot yet define it in a given time, to name it properly when it is still an agnostic, vague state for the intellect." ${ }^{8}$ Next, he continues: "Conscience is the generic feeling of the absolute ideal, which occurs most strongly when it has to do with something that contradicts the ideal." ${ }^{\prime 9}$ Thus, the basis of ethics is, in the light of this concept, emotional intuition, the content of which seems autonomous in the cognitive process, free from intellectual schemes, but here we also have a case where the ethical content of an agnostic experience leads to its metaphysical explanation.

At the turn of the century the ethical thought of Polish positivists was still active. Their merit was posing the problem of the possibilities and scope of scientific ethics. They limited it first to ethology, i.e. descriptive ethics, but with time they asked about the conditions of scientific

${ }^{6}$ Which corresponds to the states of consciousness disorder analysed by Sigismund Freud as far back as in the nineteenth century as an inability to describe what one is experiencing.

7 E. Abramowski, Metafizyka doświadczalna i inne pisma, compiled by and introduction by S. Borzym (Warszawa: PWN, 1980), 64 .

8 Ibidem, 590.

9 Ibidem, 592. 
justification of normative ethics. This problem was addressed by Julian Ochorowicz (1850-1917), who analysed the problem of the scientific nature of ethics and its independence in his competition dissertation Method in Ethics (1906). In accordance with the spirit of positivism, what he understood as science was ethology, those areas of research which, in many ways, describe the structure and development of human ethos (morality), while the problem for him was the scientific nature of proper or normative ethics. While ethology obviously clung to the world of facts, that is, to the moral experience of generations, which is a kind of ethical induction, normative ethics was supposed to indicate the duties and deal with shaping moral attitudes. However, Ochorowicz saw methodological difficulties in combining descriptive and normative ethics. He understood that normative ethics could not easily be based on the inductive results of descriptive ethics. "The universal history of morality", as he wrote, "is precisely this one great, complicated, but comprehensive ethical experience, which cannot be replaced or supplemented in a laboratory manner."10 Making ethics scientific would have to be done on the transition from inductive results of descriptive ethics to normative ethics, with the methodological problem of the transition from the realm of facts to the realm of duty standing in the way. "The mystery of this transition", he wrote, "once explained, would dispel the rest of the doubts." 11

Difficulties inclined positivists towards the postulate of building independent ethics. Ochorowicz treated its formula as inaccurate because, as he claimed, ethics must be somehow dependent on experience, but on the other hand he believed that it does not need to support itself on the "general philosophical system", and can even "precede it and develop without it at all."12 Here we can observe an important question of seeking a methodological way to legitimize a specific experience as the basis of ethics. The positivists posed a question, but did not find and describe such a basis.

The anti-naturalist philosophy of values of Stanisław Brzozowski (1878-1911), a philosopher, writer and publicist, progressed much further in this direction. He called ignoring the issue of values "naturalistic daltonism."13 In his philosophy of deed, values were treated as a foundation for the becoming of reality, irreducible to the description of facts. Values are primordial in relation to being: in relation to history, they

10 J. Ochorowicz, "Metoda w etyce”, Przeglad Filozoficzny 1906, v. 1, pp. 25-26.

11 Ibidem, 47.

12 Ibidem, 12.

13 Cf. Stanisław Brzozowski, "Monistyczne pojmowanie dziejów i filozofia krytyczna" (1904), in: idem, Kultura i życie. Zagadnienia kultury i twórczości w walce o światopogląd (Warszawa: Księgarnia Polska B. Połonieckiego; E. Wende i S-ka, 1936), 230. 
are "the birth point of being", "the element of the world". He wrote: "It is not a closed, dead, finite existence, but a deed that is the essence of the world." 14 Here the process of recognizing values is closely connected with the deed, it has features of subjectivity, but [also] concern about what is right, about objectivity. Unfortunately, there is no separate place here for a developed intuitive epistemology of values, although Brzozowski can be generally but not without many doubts classified as belonging to the intuitive current of value-determining cognition. Antinaturalism creates a bearing where values are given directly, intuitively.

The philosophy of values of Florian Znaniecki (1882-1958), whose early work was devoted to the philosophy of values, was equally antinaturalistic. Anti-naturalistic in its nature is the conviction based on the analysis of typical historical examples of value deduction from the concept of being, that "a direct deduction of values from substantial being is impossible." ${ }^{15} \mathrm{He}$ believed that in order to work around this in practice, one chooses, from among the many recognized values, a value that can be incorporated into the metaphysical system and absolutized, and then one can derive other values out of it and build relationships with other values. According to Znaniecki, the world of values is given to us directly. "We have to assume that direct reality is an unlimited variety of separate concrete values, that only values are given to us directly and nothing more."16 However, he considers this direct experience of values as subjective, borrowed from the past, in reflection, theories or systems. Thus, as he claimed, there is no "pure experience". He wrote, "If there is anything absolute, it is only as the final boundary of a cognitive process - a boundary that is perhaps not attainable - and never as the starting point of cognition." 17 Value is that very current content of cognition that is borrowed from the past and turned to the future, combining the subjective and objective sides of experience. Values fill the boundaries of reality that expand in the process of experience.

Thus, value is the content of the current experience, the object of cognition given in the perspective of apperception as a cognitive endowment, the subject's attitude - it is cognitively borrowed content, although it seems to be given directly. This borrowing has its developmental logic in history, and thanks to its openness to new experiences that resist systems, it is a creative process, the basis of the dynamic structure of practical reality. New relations of values are still being created in it, and the

${ }^{14}$ Ibidem, 262.

${ }^{15}$ Florian Znaniecki, Zagadnienie wartości w filozofii (Warszawa: Skład główny w Księgarni E. Wende i S-ka, 1910), 30.

16 Ibidem, 114.

17 Florian Znaniecki, Humanizm i poznanie (Warszawa: Skł. Gł. w Księg. E. Wende i S-ka, 1912), 38. 
broadening experience influences the modification of the scope and structures of systems. Without going into details, one can risk a claim that the experience of values is in Znaniecki's case any content extracted from nothingness (chaos), but extracted in the light of the theory and perspective formed by the past. At the limits of value cognition there are still unknown values that the system can incorporate or reject and leave in the world of evil (of what is given to us but does not fit into the system of positive values). The experience of a negative value is thus borrowed in relation to the system of positive values, but by exclusion from the system.

Znaniecki's anti-naturalistic attitude from his first works weakened in the 1920s. In the Tasks of philosophical synthesis (1927), he assumed that the world of values requires a link between genetic (ontological) synthesis and the axiological (logical) one to be properly addressed. The former represents the inductive experience of values, their validity rooted in the past, while the latter expresses a systemic approach to values, their internal logic and importance. The two perspectives are providing each other with additional details. The system is important if it overlaps with the field of experience. "A non-existent system cannot be valid; each system is only valid as long as it exists" - says Znaniecki. ${ }^{18}$ The permeation of the existence of values with their systemic logic is an extremely important characteristic of the creative practical reality where our experience of values is borrowed from the system, but at the same time the induction determines the scope of the system's validity. The empirical and rational perspective of the representation of values is marked by the relativism of value cognition (borrowing) until the fields of both syntheses overlap, determining one absolute synthesis. The possibility of such a synthesis is open as the empirical, historical perspective draws closer to the system and axiological perspective. This would mean that the deductive value systems would have full support in the inductive value experience field. This is the motif that has been marked by philosophical ethics for centuries, in that there is a demand for the universality and certainty that only a system can give, but ethics would be an empty form if it were not confirmed in experience, in practice. Moral experience is therefore essential for ethics.

The quoted researchers of the world of values assume the directness of the cognitive representation of values in various ways. Between the positivism of Ochorowicz, who saw the possibility and need to base ethics on an experience specific to it, and Abramowski, who placed it in the metaphysics of the "unconscious", in the intuition (agnosia) of the ideal of brotherhood, and - going further - Brzozowski and Znaniecki, who

18 Idem, Zadania syntezy filozoficznej, in the volume of the same, Pisma filozoficzne, vol. 1, compiled by and introduction by Jan Wocial (Warszawa: PWN, 1987). 
took into account, to varying degrees, the methodological anti-naturalism of the cognition of values, there are certain differences in positions in the understanding of direct cognition or intuition. All of them have presented this cognition as direct, that is, experimental. Abramowski assumed the certainty of agnosia, but he understood the intuition of the ideal as a process in which the experience of evil, harm, resistance of conscience, and feelings play an important role pointing to the ideal. For him, the path of cognition is a process of freeing oneself from the relativisation contained in intellectual patterns. Brzozowski also seeks non-relativistic support for axiological creativity that objectifies itself in action, in work. Meanwhile, Znaniecki saw the cognition of values as the matter of cognition and as a process completely entangled in systemic relativisations created under the pressure of new experience of value and axiological creativity. This is a process of organizing values, recognizing what is absolute, non-relative in the world of values, since only this approach to values can be given to us directly. Each of the thinkers referred to in this article, who formed the basis of the Polish philosophy of values and ethics, indicated directness in learning about values, but it is a subjectmatter directness; it is another thing to borrow the process of cognition and its result from subjective, individual, cultural conditions, theories or value systems. As a result of such an interpretation, the problem of certainty of value cognition arises if it is borrowed from previously formed theories and systems. It follows from the work of the aforementioned thinkers that axiological contents borrowed from systems are marked by a methodological self-consciousness that is oriented towards reducing uncertainty and searching for absolute value. The closest to recognizing such a value is Abramowski.

When outlining the field and nature of direct cognition in the world of values and morality, these thinkers generally did not use the term "intuition", as it was most often associated with the anti-intellectualistic understanding of intuition in Bergson's philosophy at the time. Only Abramowski called his agnosia intuition, but then again, he agreed with Bergson's anti-intellectualism. Although intuition was not a category of the theory of cognition in the sphere of values and morality, it can be assumed that the method of cognition or ideals has the character of a direct cognitive view, whose dogmatism and comprehensiveness is not yet resolved. 


\section{Intuitionism in Scientific and Independent Ethics}

The issue of ethical cognition was referred to in his lectures by Kazimierz Twardowski (1866-1938), founder of the Lviv-Warsaw School. It is impossible to unambiguously qualify his ethical thought as anti-naturalism, and thus to incorporate it into the current of intuitionism. The world of values is understood here above all according to the classical teleological scheme: good is the object of aspiration, interest, and purpose. Twardowski seems to follow Aristotle's approach to good as the goal of any aspiration. At the same time, however, as a student of Brentano, an Aristotelian, he is not satisfied with a simple registering of aspirations as values, but asks about their rightness, i.e. their compliance with the ethical criterion for resolving conflicts of aspirations. The field of aspiration (the world of the value-determining experience) creates a material field of ethics (axiological theory) that is subject to the ethics of the criteria of duty. The justification of the ethical criterion was for Twardowski the most important difficulty on the way to scientific ethics. It seems that in search of a satisfactory justification he was approaching an intuitionism related to Brentano's and Moore's concepts, but it is difficult to find a clear classification ${ }^{19}$. This is an open matter for scientific ethics, which he distinguished from the religious, personal one.

The scientific ethics, discussed in the Polish philosophical circles at the turn of the nineteenth and twentieth centuries, has not yet formulated, according to Twardowski, any certain epistemological criterion of ethics, and therefore nothing remains, but to assume the one best justified. For Twardowski, it was the liberal-utilitarian model of ethics, trying to reconcile the freedom of the individual with the requirements of social respect for the freedom of others. The scheme perfectly fits the following view: "the object of ethics is the conditions under which the contact between the spheres of action of different individuals involves as few mutual limitations as possible." ${ }^{20}$ Ethics thus turns out to be "the science of how to reduce the opposites between individuals as far as possible". It is precisely the reduction of mutual limitations that is a positive ethical criterion. Twardowski made this criterion concrete by referring to two historically proven ethical norms, the principle of justice and the principle of love. Ultimately, referring to the sphere of human aspirations and the proved principles of regulating the conflicts of these aspirations makes his ethics, on the one hand, empirical, although there is no clear boundary between factual and moral experience, while on the oth-

19 Cf. Ryszard Jadczak, Człowiek szukajacy etyki. Filozofia moralna Kazimierza Twardowskiego (Toruń: Wydawnictwo UMK, 1993).

${ }^{20}$ Kazimierz Twardowski, “O zadaniach etyki naukowej”, Etyka 12: 139. 
er hand, the philosopher realizes the existence of a priori ethical content, revealed in the adoption of general axiological and normative axioms. As a methodologist who tried to clearly distinguish between the a posteriori and a priori sciences, he also tried to transfer this division into the area of ethics. Because of the complexity of its subject matter, he did not carry out this idea of drawing a clear line between what is a priori and what is a posteriori in ethics. However, the nature of this boundary and the mechanism of this encounter is one of the most interesting and at the same time the most difficult problems in ethics. A similar trail of methodological research can be found in the Znaniecki's concept of philosophical synthesis (Tasks of Philosophical Synthesis, 1927) discussed above, which combines a genetic (historical, ontological) perspective with an axiological (logical) one. This is the problem of place and the role of induction and deduction in ethics.

Władysław Tatarkiewicz (1886-1980) belongs to a wide range of schools; he studied in the West, but obtained his habilitation (postdoctoral degree) in Lviv. He enjoyed the analytical way of practicing philosophy in Lviv, but had a sense of his own distinctiveness. In his habilitation thesis On the absolute nature of good (1919) and many shorter works on axiology ${ }^{21}$ and ethics, ${ }^{22}$ he defended intuitionism in ethics without using this ambiguous term. As the basis of ethical reasoning he took the order of general and abstract judgements on values, i.e. the "primary" sentences such as "A is good", "B is bad", "A is better than C". The author of On the absolute nature of good was inspired by the views, of G.E. Moore, F. Brentano, and M. Scheler, which were popular at the time, but the construction and role of judgements on good and evil is modelled after the Aristotelian structure of the first principles of knowledge, in which the main axioms of the system are not justified, just as the original terms are not defined. Value-determining judgements, as he wrote, cannot be justified indefinitely - "one has to stop at a sentence about good, accepting it without proof." ${ }^{23}$ Ethical judgements, like those of Aristotle, have their specificity and structure of justification, analogous to

${ }^{21}$ Cf. Władysław Tatarkiewicz, O bezwzględności dobra (Warsaw: Gebethner i Wolff, 1919); idem, "Ce que nous savons et ce que nous ignorons des valeurs", Actualités Scientifiques et Industrielles 539: Travaux de IX Congres International de Philosophie, vol. 10 (Paris, 1937); Cf. Idem, "Von der Ordnung der Werte", Actualités Scientifiques et Industrielles, N 851. Publications de l'Institut International de Collaboration Philosophique, III - Amersfoort, 1938 (Paris, 1939); idem, “Les problémes en axiologie: argument écrit", Actualités Scientifiques et Industrielles, N 1078. VI - Lund, 1947 (Paris, 1949). These three papers were published in Polish in Ruch Filozoficzny LXVII, 4 (2010).

22 Cf. idem, "O czterech rodzajach sądów etycznych", Przegląd Filozoficzny 33, 4 (1930); idem, “Obrachunki i nakazy; uczciwość i dobroć”, Etyka 1 (1966).

${ }^{23}$ As cited in: idem, "O bezwzględności dobra", part III, 7; in: idem, Droga do filozofii i inne rozprawy filozoficzne (Warszawa: PWN, 1971), 269. 
theoretical knowledge. The philosopher in the Topics mentioned three types of premises of syllogisms: logical, physical, and the very ethical ones, concerning sentences about good and evil. ${ }^{24}$ Since sentences about good cannot be derived from sentences about facts, nor from the definition of good, because there is no such definition in the classical sense, it must be assumed that at the basis of ethics there are its "primary" judgements, the main principles of ethics, and similarly, that its basic concept, and good or value is undefined in this respect, because the underlying concepts of a discipline are not defined.

Thus, in Tatarkiewicz's case, the foundation of moral cognition is based on a rationalistic model of theoretical knowledge, adopted for the use of ethics in the broad sense of the word, in which absolute and objective values are at the basis of practical reasoning, judgements of rightness, relativised to specific circumstances, determining by means of a calculation of goods, what in a given set of circumstances realises the optimum value, what is the best possible action. Tatarkiewicz observes with time that a calculation cannot be the only way to formulate the rules of rightness of an act, although it remains the basic tool to define them. An old dispute between deontological and teleological ethics was at stake here, which was resumed at the beginning of the twentieth century by H. A. Prichard, arguing against G. E. Moore with a criticism of the concept of rightness based on the calculation of goods, their comparability in concrete circumstances, where good meant as much as "good for something". Prichard claimed that the rules of conduct are based on what is obvious, the intuition. Tatarkiewicz, referring to this dispute, took the following position: "[...] simultaneous acceptance of both positions seems possible. Namely: in some cases orders (emotional or other) are in force and require us to determine the right course of action in one way or another. In other cases, however, probably more often, no firm and explicit order is faced by the person acting; then it is possible and necessary to calculate the goods. [...] In this sense, it can be said that the theory of calculation of goods and the theory of orders can be combined, and complement each other. [...] The examination of goods and moral orders (even if they are understood broadly and include both the orders of integrity and goodness) do not constitute a complete disjunction. Namely, in some cases, we act without a calculation, and at the same time without reference to orders, but in accordance with a direct feeling, an impulse, and with an unexamined awareness of righteousness. ${ }^{25}$

Therefore, even though Tatarkiewicz did not use the notion of intuition, he recognized, at the basis of ethical cognition, the first judgements

${ }^{24}$ Cf. Arystoteles, Topiki, 104a 8.

25 Tatarkiewicz, Obrachunki i nakazy, uczciwość $i$ dobroć; I am quoting the issue published in the volume: idem, Droga do filozofii, 303-304, 307. 
on values that were not required to be justified, which were the axiological premises of the practical judgements of rightness formulated in the mode of calculation of goods under specific circumstances in which a person would have to act. Apart from this route, in practical situations he allowed for the observance of obvious rules (orders and prohibitions), and further on, even behaviour dictated by impulse. Directness (intuition) is thus transferred to the obviousness of obligations and impulses. Hence we are dealing here with a limited meta-ethical pluralism in the field of ethical cognition, with the dominant role of the calculation as the source and a test of the legitimacy of norms. What is intuitively given as a rule or an ethical impulse that does not require a calculation of its value, in his opinion, has a cognitive foundation, borrowed, however, from the judgements of the "primary" ethics and the calculation of goods.

Tadeusz Kotarbiński (1886-1981), a Lviv student of Twardowski's referred to the discussion from the turn of the nineteenth and twentieth centuries on the possibility of formulating independent ethics. The return to the topic of independent ethics came at a time of the worldview confrontation in Poland after World War II. Thus, in a fairly common sense, independent ethics was understood as "free from religious assumptions." 26 The philosophical roots of such independence of ethics lie in the eighteenth-century free-thinking movements, and later in Scientism and Marxism. But this is a narrow understanding of independence. The independence of ethics from religion does not yet provide a developed concept of justification, but it limits the source thereof. Thus, more important for Kotarbiński was the second way of understanding of the independence of ethics, which he described as independence from any worldview, including the philosophical one. Such independence integrates ethics into the current of autonomous ethics, based on its own premises, which he called 'the obviousness of the heart', common to people who profess different world views. What turns out to be important in this respect is the question of the method of justifying human reactions to what is good, what is bad, what is worthy of respect, and what deserves contempt. He wrote: "We want to do it empirically, experimentally, on the basis of observation and reflection on its data." ${ }^{27}$ Such empiricism, however, is put in an anti-naturalistic perspective. In Kotarbiński's opinion, one cannot go beyond ethics in the justification of claims or ethical attitudes. He wrote: "Ethical certainties, in the form of statements that this and that, of course, is venerable, this, of course,

26 Tadeusz Kotarbiński, "Zasady etyki niezależnej”, Studia Filozoficzne 2, 4 (1958); as cited in: idem, Studia z zakresu filozofii, etyki i nauk społecznych (Wrocław-Warszawa-Kraków: Ossolineum, 1970), 194.

${ }^{27}$ Idem, "Zagadnienia etyki niezależnej", Kronika 21 (1956), as cited in: idem, Studia z zakresu filozofii, etyki i nauk społecznych, 209. 
is disgraceful, must be important components of the justifications. [...] This is as empirical as the behaviour of the observer, who investigates, by means of his own taste reaction, which liquids are sour." ${ }^{28}$ There is no doubt that we are dealing here with a methodological parallelism between moral cognition and the world of things, nature.

Kotarbiński is undoubtedly an ethical intuitionist. In numerous statements on independent ethics, the name of which has, somewhat inappropriately, been associated with his views, he has tried to explain the cognitive basis of the ethics understood in this way, but he mainly used the analogy to sensual cognition and the fact that his position has its philosophical equivalent in the views of thinkers indicating the methodological specificity of ethical and moral beliefs. "After all, for everyone who is more or less familiar with the literature of the subject," he wrote, "the literary kinships of this text with what can be read in the writings of Brentano, Moore, Husserl, Petrażycki, are clear [...]. What is more, with what is contained in the catechism after the theological ingredient was drained from it." 29

There is also the third meaning of independent ethics, about which Kotarbiński wrote: "Independent ethics is independent also in the sense that one's own voice of conscience cannot be replaced by that of others." ${ }^{30}$ This is one of the most frequently quoted terms of independent ethics, which has a humanistic dimension, but also begs questions about the epistemological status of conscience. Everyone who critically examines the functioning of the conscience knows that, despite strong, non-rejectionable moral convictions in specific situations, conscience has, nevertheless, a subjective factor, it can be mistaken. It is difficult to regard it as certain in an objective sense. Kotarbiński has not been discouraged by this, though. The criterion of cognitive validity for basic ethical evaluations is obvious "in the sense that $2 \times 2$ is obviously four, in which the father is obviously older than the son. Or the annoyance of a severe toothache is obviously greater than the annoyance of putting an over-salted piece of meat in the mouth." ${ }^{31}$ The obviousness understood in this way, analytical or sensual in this respect is to be analogous in the sphere of judgements and attitudes. To give an example of an opposition of judgements: "Good people take in a poor orphan and raise the child like their own with all due care. Therefore, of course, they deserve to be respected. A bad man, a sadist, a domestic tyrant, bullies his children, beats them terribly with fury for anything. He is then rightly

\footnotetext{
${ }^{28}$ Idem, “Zasady etyki niezależnej”, ibidem, 205.

29 Ibidem, 193.

30 Idem, "Zagadnienia etyki niezależnej", ibidem, 220.

31 Idem, "Zasady etyki niezależnej", ibidem, 196.
} 
drawing outrage at himself for his shameful deeds." ${ }^{32}$ The basis of ethics is, therefore, intuitive attitudes and acts of people, directly given to the conscience to be evaluated, subject to generalisation in the experience of individuals and societies, but this is not the induction of fact, but the induction of judgement. The result of the moral experience leads Kotarbiński to formulate the ideal of a reliable guardian, characterized by a good heart, honesty, courage, bravery, and composure.

Kotarbiński's ethical work was essayistic in nature, with a high degree of communicativeness. Its ethical ideal was based on numerous references to the examples of consensual judgements in spite of philosophical or worldview differences. This ethics, however, aroused criticism in the methodological sphere and was accused of being in fact an ethological description, a generalisation of the facts of judgement (Maria Ossowska). However, there were also positive references which drew attention to the boldness of basing ethics on methodological values, on moral experience, but also on the limits of such an approach (Fr. Tadeusz Styczeń).

While Kotarbiński focused on the independence of ethics, his university colleague, Tadeusz Czeżowski (1889-1981), one of Twardowski's closest students and continuators of Twardowski's methodology and spirit of philosophy, the author of a small but famous dissertation Ethics as empirical science (1949, the final version of 1956), ${ }^{33}$ began research into the possibility of scientific ethics. He also gave the independent ethics of Kotarbiński a more precise interpretation. Both were in favour of the empirical foundation of ethics and its methodological independence from any metaphysics or worldview, except that Czeżowski in subsequent works described ethics as a science analogous to other sciences, as one of the philosophical sciences.

The basic assumption of Czeżowski's scientific philosophy is the belief that science functions in two basic dimensions: logical and empirical. Experience is for him a source and test of scientific knowledge, while logic provides forms of thinking. The methodological structure of ethics is analogous to the methodological structure of science. The empirical base of ethics is also analogous to the base of natural sciences, employing observational sentences or introspection. Czeżowski understands each experience as a source-intuitive cognition, and at the same time, devoid of dogmatism, subject to verification. By intuition Czeżowski means direct, inexplicable cognitive acts in the sensual, introspective,

32 Ibidem.

33 First printed in: Kwartalnik Filozoficzny XVII (1949): 161-171; also in: Philosophy and Phenomenological Research XIV, 2 (1953). The edition quoted here is from the volume: Odczyty filozoficzne, 2nd edition (Toruń: Wydawnictwo UMK, 1969). 
and axiological fields. ${ }^{34}$ Referring to Hume, Brentano, and Moore, he extended the concept of experience to the world of moral and aesthetic values. The latter values were of little interest to him, and he made moral experience the basis of scientific ethics.

A unit of experience is judgement, and the empirical basis of ethics is therefore formed by individual, repeatable and comparable judgements. In order to make a judgement, it is necessary to present its subject and take an evaluative attitude towards it. The object can be given in a perceptual image or in an abstract concept. The judging attitude is analogous to attention as a cognitive attitude. As in the cognitive attitude one determines existence (idiogenic theory of judgement), so in the judging attitude one determines value. A judgement is true if the object is valuable, and false if it is not. Judgements can be wrong, and can be corrected by checking them, repeating them in various conditions and comparing them to each other. The ability to judge develops with the experience of the person judging the object and undergoes improvement.

What is characteristic of the cognitive status of a judgement? Czeżowski puts it as follows: "judgements are directly justified as perceptive beliefs, that is to say, when determining the value of an object we rely on a kind of obviousness of judgement which, again, like a perceptive belief, cannot be proved, in other words, cannot become a conclusion of deductive evidence [...] The formation of judgements is sufficiently explained by an approach which assumes that the presentation of an object becomes a motive for judgement against the background of the judging attitude". ${ }^{35}$ Thus at the heart of a moral judgement there is the act of direct cognition. Unlike in M. Scheler's phenomenological ethics of values (emotional a priori) or in Kotarbiński's independent ethics (obviousness of hearts), Czeżowski's judgements are intellectual acts. If a feeling appears, it is secondary to judgement. He wrote: "Therefore, the judgement is not conditioned by the feeling as the motive for giving it, but, on the contrary, both types of feelings connected with judgements, i.e. aesthetic and value feelings, are based on judgement - pleasure or pain appears against the background of giving judgement." ${ }^{36}$ It is also a feature of value feelings that they arise from beliefs about the existence of the subject being judged, while value judgements motivated by an analytical belief do not condition emotion as a moral feeling.

Values are non-definable, they can only be pointed out, learned intuitively, i.e. captured in the acts of direct and comprehensive cognition. Their non-definability results from the fact that they belong to the

${ }^{34}$ Cf. Tadeusz Czeżowski, Filozofia na rozdrożu. Analizy metodologiczne (Warszawa: PWN, 1965), 71.

${ }^{35}$ Idem, "Etyka jako nauka empiryczna", in: idem, Odczyty filozoficzne, 41.

${ }^{36}$ Ibidem. 
transcendentals and thus are not representative, they are ways of being (modi entis), they exceed the category arrangement, they are not traits, but such arrangements of traits given in the representation that the objects are good or beautiful, and we judge them as such.

Ethics is therefore an empirical science with a logical structure and, like any science, "is an interpretation of logical theories [...] from which the principles of building its sentences and the principles of its reasoning are derived" ${ }^{37}$ The field of interpretation in ethics is the experience of moral values (content of judgements). Czeżowski, referring in a way to Twardowski, distinguishes between hypothetical and deductive theories built "from the top down". which have a structure analogous to the one of axiomatic sciences, and empirical-inductive theories, built "from the bottom up". The norms functioning within the scope of axiomatic ethics are of a formal-deontological nature; they order to act in accordance with the definition of morality provided in the main norm. The primordial axiom of morality (the primordial norm) is reached through an analytical description. Its idea is that on the basis of a limited range of experience, the ethical principle created in the field of induction is being axiomatized. What is still subject to generalisation and checking in the subsequent acts of judgement, in the analytical description is subjected to a universalising intuition, in order to further provide a starting point for ethical deductions in the field of moral experience. Just as empirical-inductive ethics strive to determine the supreme values of life, axiomatic-deductive ethics aspire to be applicable in practice; they need confirmation in life and only then do they receive material truthfulness. The field of axiological empiricism is an area of semantic interpretation of axiomatic ethics, a test of its applicability, a proof of ability to regulate attitudes, to solve conflicts. In this way empiricism and reason meet again. Thus, everything happens in the same way as in scientific cognition, ${ }^{38}$ only that it is a different dimension. This is a fundamental problem for ethics: the field of moral practice, the ethical judgements contained in it, provide a heuristic basis for the axiomatic representation of an ethical principle (ethical theory), while an ethical axiom, with its absoluteness and objectivity, is subject to the constant testing of life. One might add that the material validity of ethics is related to its scope of application. This alignment of the a priori and a posteriori perspective in ethics replaces the motif of transcendentalism absent from the Lviv-Warsaw school ethics and Kant's absence, and also resembles the relationship of two syntheses, axiological and logical in the works of Znaniecki.

${ }_{37}$ Czeżowski, Filozofia na rozdrożu, 179-180.

${ }^{38}$ Cf. idem, "Aksjologiczne i deontyczne normy moralne", Etyka 7 (1970). 
In this brief picture of Czeżowski's metaethics, he appears to be the most methodologically conscious of the importance of intuition in science, as well as in ethics, which he considered to be an empirical science, acting logically in the field of the proper empiricism. One can say that intuition appears twice in his views: firstly in the field of experience, for the first time in individual judgements of values, subject to generalization and verification, and secondly in the act of axiomatisation of experience resistant to falsification into the supreme norm of the ethical system, which is described by some ethicists as universalising intuition. The process of interpretation of the ethical system in the field of axiological empiricism is another turn towards intuition, but one structurally borrowed from the system.

Czeżowski's views are the most precise theory of intuition and obviousness found in Kazimierz Twardowski's circle of students. What is important is that intuition, as a direct and comprehensive act of determining values, loses its infallible status in his ethical metatheory, but thanks to control procedures, it turns out to be an irremovable element of cognitive procedures in ethics.

\section{Summary}

At this point one can offer only a partial summary of the description and analysis of varieties of ethical intuitionism in the ethical and meta-ethical work of the first anti-naturalists and intuitionists of the twentieth century and the Lviv-Warsaw School. A concise review of the work of Polish philosophers indicates the process of reaching acceptance of intuitive foundations of ethics and philosophy of values. It manifests itself in the use of intuitionistic terminology and methodology. Only Abramowski, with full methodological awareness, used the term "intuition" to describe the status of ethical agnosia, while Ochorowicz declared the need to find a cognitive basis specific to ethics. In this sense he was a methodological anti-naturalist, but only in the critical dimension. Similarly, Brzozowski appears as an anti-naturalist in his philosophy of deed, yet the methodological basis of value-determining beliefs is not described in more detail in his works. It is only Znaniecki, as a declared anti-naturalistic methodologist, with respect to the cognition of values and ethics, who realizes the role of direct cognition as a foundation, a cognitive matter that we nevertheless form and target in the perspective of apperception, theory, and systems of knowledge and values. This is the discovery of the role of borrowing of the cognition of values from the established past experience, subjectively conditioned (humanistic factor). Thus, while Abramowski was moving towards the reduction of apperception, Znaniecki discovered its role so as to show in the Tasks of philosophical 
synthesis the interplay of both factors, two syntheses, one of which represented growing axiological empiricism, while the other demonstrated the role of logical synthesis, forming a system of value arrangement.

The article also describes the development of independent ethics and aspirations towards making it scientific in the ethical thought of Twardowski, Tatarkiewicz, Kotarbiński, and Czeżowski. The problems posed and analysed by Twardowski have been reflected in the work of his students. Tatarkiewicz's ethics (philosophy of values) has been influenced the least by Twardowski, who recognized intuitionism similar to that of Moore in the treatise On the absolute nature of good. Tatarkiewicz, however, was more close to Aristotle in this work, treating the primary judgements as the guiding principles of the knowledge system. It was only in the late period of his work that he saw a place in ethics for concrete-individual intuitions, but again he pointed to their possible borrowing from ethics in the axiological foundations that constitute the axiological basis for formulating the rules of rightness. Kotarbiński, on the other hand, was a declared intuitionist, but ambiguous in his attempts to describe the methodological basis of ethics (he compared the ethical conviction to both mathematical sentences and sensual observations. He basically attributed the cognitive function to the conscience, while the criterion of moral cognition to the "obviousness of the heart". It was only Czeżowski who organised the ideas of scientific ethics by describing the intuitive, empirical foundation of ethics, which by means of induction creates ethical (teleological) laws. Only with time was this description supplemented by an axiomatic-deductive model based on a universalised intuition, which has as its basis a moment of some limited moral experience. Thus, Czeżowski used two kinds of intuition: one analogous to observational sentences, and one analogous to general, a priori primary sentences founding the ethical principle which determines what behaviour is moral in the axiological (teleological) field.

Let us try to conclude with a preliminary division of intuitionism in ethics, taking into account some selected features of intuition:

1. With regard to the manner of understanding (character) of the act of moral intuition, in accordance with the tradition of division of positions in the dispute over the sources and justification of cognition, the following types of intuitionism are mentioned:

- empirical: quasi-sensory (moral intuition is an educated function of a specific moral sense, a function of conscience acting as the "eye of the soul" in acts analogous to observation, directed towards individual, concrete deeds); its criterion is obviousness.

- rationalistic: quasi-mathematical (moral intuition functions in the mode of axiomatic, a priori assumptions of moral argumentation, and is thus directed towards the general properties of deeds). 
2. With regard to the original nature of the intuitive cognitive act, intuitionism can be:

- intellectualistic (intuition is intellectual, it is a value-determining judgement or normative judgement that precedes a feeling);

- emotionalistic (moral intuition speaks through feelings of value, and these acts can be understood both as individual experiences and as a priori general judgements);

3. Because of the formal object of intuition, intuitionism is divided into:

- axiological (the object of intuition is goodness, values, and the way they are realized in life requires the recognition of what is right, by calculating goods for achieving the best results in given circumstances);

- deontological (the object of intuition is a duty or obligation, general or specific orders to act in a certain way; there are some obvious duties, prima facie, beyond discussion; we learn first and foremost the duties; in other words, we learn the rightness of acts intuitively and not by reasoning).

Let us try, by way of example, to insert into the above division of intuitionism in ethics the views of the Polish philosophers discussed above, leaving as unresolved the positions of Ochorowicz, Brzozowski, Twardowski, and Kotarbiński. And so:

- Edward Abramowski certainly represents empirical intuitionism of an emotionalistic nature, and the object of intuition is rather values (the ideal of brotherhood);

- Władysław Tatarkiewicz represents above all rationalistic, intellectualistic (not emotionalistic) intuitionism, directed towards absolute and objective values; only in the background did he allow intuition of general duties and empirical intuition (moral reflex);

- Tadeusz Czeżowski represents empirical, intellectualistic, and axiological intuitionism, but as he defines his views and incorporates them into the structure of scientific theory, he assumes that at the base of axiomatic ethics are rationalistic and deontological intuitions.

Other Polish supporters of intuitionism in ethics include Henryk Elzenberg, Roman Ingarden, Karol Wojtyła, Tadeusz Styczeń, and Marian Przełęcki. These will be addressed in the second part of this article. There will also be room for additional conclusions for a general summary of intuitionism in contemporary Polish ethics. 


\section{Bibliography}

Abramowski Edward. 1980. Metafizyka doświadczalna i inne pisma, compiled by and introduction by S. Borzym. Warszawa: PWN.

Brzozowski Stanisław. 1936. Kultura i życie. Zagadnienia kultury i twórczości w walce o światopogląd. Warszawa: Księgarnia Polska B. Połonieckiego; E. Wende i S-ka.

Czeżowski Tadeusz. 1970. "Aksjologiczne i deontyczne normy moralne". Etyka 7.

Czeżowski Tadeusz. 1965. Filozofia na rozdrożu. Analizy metodologiczne. Warszawa: PWN.

Czeżowski Tadeusz. 1969. Odczyty filozoficzne, 2nd edition. Toruń: UMK.

Drabarek Anna. 2008. Intuicyjne poznawanie dobra w rozważaniach G. E. Moore'a $i$ W. Tatarkiewicza. In: Wiedza a intuicja, ed. A. Motycka. Warszawa: Wydawnictwo IFiS PAN

Jadczak Ryszard. 1993. Człowiek szukajacy etyki. Filozofia moralna Kazimierza Twardowskiego. Toruń: UMK.

Kotarbiński Tadeusz. 1970. Studia z zakresu filozofii, etyki i nauk społecznych. Wrocław-Warszawa-Kraków: Ossolineum.

Moore George Edward. 1919. Zasady Etyki [Principia Ethica], transl. Cz. Znamierowski. Warszawa: Wydawnictwo M. Arcta.

Motycka Alina (ed.). 2008. Wiedza a intuicja. Warszawa: Wydawnictwo IFiS PAN.

Ochorowicz Julian. 1906. "Metoda w etyce", Przeglad Filozoficzny.

Soldenhoff Stanisław. 1969. O intuicjonizmie etycznym. Obowiazek i wartość w systemie W. D. Rossa. Warszawa: PWN.

Tatarkiewicz Władysław. 1937. "Ceque nous savons et ce que nous ignorons des valeurs". Actualités Scientifiques et Industrielles, N 539: Travaux de IX Congres International de Philosophie, vol. 10. Paris.

Tatarkiewicz Władysław. 1949. "Les problémes en axiologie: argument écrit". Actualités Scientifiques et Industrielles, N 1078. VI - Lund, 1947. Paris.

Tatarkiewicz Władysław. 1939. "Von der Ordnung der Werte". Actualités Scientifiques et Industrielles, N 851. Publications de l'Institut International de Collaboration Philosophique, III - Amersfoort. Paris.

Tatarkiewicz Władysław. 1971. Droga do filozofii i inne rozprawy filozoficzne. Warszawa: PWN.

Twardowski Kazimierz. 1971. “O sceptycyzmie etycznym. Wykładów z etyki część II", compiled by Izydora Dąmbska, on the basis of outlines mainly from 1923/1924. In: Etyka 9.

Twardowski Kazmierz. 1973. “O zadaniach etyki naukowej”. Etyka 12.

Wiśniewski Ryszard. 1979. "Intuicjonizm w aksjologii Władysława Tatarkiewicza”. Acta Universitatis Nicolai Copernici, Filozofia 4, 103. Torun: Uniwersytet Mikołaja Kopernika.

Znaniecki Florian. 1912. Humanizm i poznanie. Warszawa: Skł. Gł. w Księg. E. Wende i S-ka. 
Znaniecki Florian. 1987. Pisma filozoficzne. Vol. 1, compiled by and introduction by Jan Wocial. Warszawa: PWN.

Znaniecki Florian. 1910. Zagadnienie wartości w filozofii. Warszawa: Skład główny w Księgarni E. Wende i S-ka.

\section{Summary}

The article summarises the achievements of Polish intuitionist ethics in the period from modernism to the Lviv-Warsaw School and compares the views by the most eminent philosophers of the time such as Edward Abramowski (1868-1918), Julian Ochorowicz (1850-1917), Stanisław Brzozowski (1878-1911), Florian Znaniecki (1882-1958), Kazimierz Twardowski (1866-1938), Władysław Tatarkiewicz (1886-1980), Tadeusz Kotarbiński (1886-1981), and Tadeusz Czeżowski (1889-1981). Finally, the author offers a systematics of their ethical standpoints as regards a) the manner of understanding of the act of moral intuition, b) the original nature of the intuitive cognitive act, and c) the formal object of intuition. The standpoints of other supporters of intuitionism in Polish ethics (Henryk Elzenberg, Roman Ingarden, Karol Wojtyła, Tadeusz Styczeń, and Marian Przelęcki) will be summarised in the second part of the article which will be published in one of the forthcoming issues of the quarterly.

Keywords: Polish philosophy, ethical intuitionism, Edward Abramowski, Julian Ochorowicz, Stanisław Brzozowski, Florian Znaniecki, Kazimierz Twardowski, Władysław Tatarkiewicz, Tadeusz Kotarbiński, Tadeusz Czeżowski 